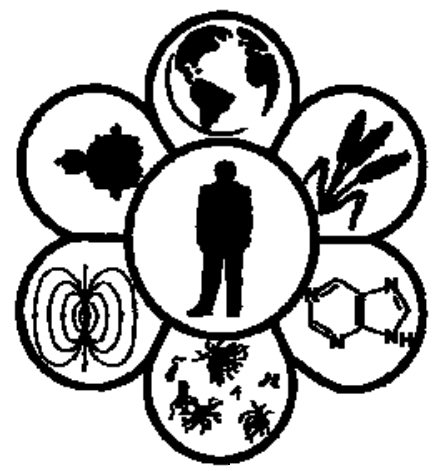

Вісник Дніпропетровського університету. Біологія, медицина Vìsnik Dnìpropetrovs'kogo unìversitetu. Seriâ Bìologiâ, medicina

Visnyk of Dnipropetrovsk University. Biology, medicine

Vìsn. Dnìpropetr. Unìv. Ser. Bìol. Med. 2014. 5(1), 28-32.

doi:10.15421/021406

ISSN 2310-4155 print

ISSN 2312-7295 online

www.medicine.dp.ua

\title{
Роль системи Нр в адаптації показників специфічного імунітету до впливу помірних фізичних навантажень
}

\author{
В.Л. Соколенко, С.В. Соколенко
}

\author{
Черкаський національний університет імені Богдана Хмельницького, Черкаси, Україна
}

\begin{abstract}
Досліджували роль фенотипу гаптоглобіну у реалізації адаптивних реакцій показників клітинної та гуморальної ланок імунітету на помірні фізичні навантаження, зумовлені заняттями фізичною культурою. У студентів після занять фізичною культурою незалежно від фенотипу гаптоглобіну достовірно знижується відносне та загальне число лімфоцитів, що $є$ типовою ознакою початкових стадій стресової реакції. Виявили статистично достовірне зниження загального числа всіх аналізованих субпопуляцій Т-лімфоцитів у студентів, які мають фенотип Нp2-2, абсолютного числа Т-лімфоцитів із фенотипами CD3+ та CD4+ у обстежених із фенотипом Нp2-1. У обстежених із фенотипом Нр2-2, після помірних фізичних навантажень вірогідно знижується відносне число хелперних Т-лімфоцитів із фенотипом CD4+, що зумовлює зниження у них імунорегуляторного індексу CD4+/CD8+, та рівень сироваткового IgG. Вірогідні зміни рівня В-лімфоцитів із фенотипом CD72+ в обстежених відсутні, незалежно від фенотипу гаптоглобіну. Підтверджено, що у формування адаптивних реакцій показників імунної системи на помірні фізичні навантаження може включатися сироваткова система гаптоглобінів. Найбільш пресинговий за таких умов фенотип - Нр2-2.
\end{abstract}

Ключові слова: гаптоглобін; імунна система; фізичні навантаження

\section{Role of Hp system in adaptation of specific immunity indices to the influence of moderate physical activity}

\author{
V.L. Sokolenko, S.V. Sokolenko \\ Bohdan Khmelnytsky Chercasy State University, Chercasy, Ukraine
}

The aim of this study is to determine the role of haptoglobin phenotype in realization of adaptive responses of cellular and humoral immunity indices to moderate exercise caused by physical training. The study was implemented in the group of second-year students aged $18-$ 20 who lived in the same climatic and geographical conditions for a long period of time. The students didn't have any acute or chronic diseases and attended the main group of physical training. 60 persons were investigated. Immune system indices analysis was carried out in September before and after physical training lessons. Leukocyte level was calculated using hemocytometer, lymphocyte level was determined on the base of blood smear (dyeing for Romanowsky-Giemsa). Expression of surface antigene by peripheral blood lymphocyte was determined by immuno-fluorescence method with the use of monoclonal antibodies. The level of immunoglobulin in plasma was determined by radial immunodiffusion or Mancini method. To assess the phenotype of haptoglobin (Hp) we used the method of electrophoresis in starch gels. In the course of research we have detected the reduction of the relative and total number of lymphocytes regardless of haptoglobin phenotype in the group of students after physical training; this is a typical feature of the initial stages of stress response. We observed statistically reliable decrease in total number of analyzed subpopulations of T-lymphocyte in the group of students with phenotype Hp2-2 which was obviously the result of changes in the general level of lymphocytes in the peripheral blood. In the group of students with phenotype Hp1-1 absolute number of T-lymphocyte with phenotype CD3+ and CD4+ is reduced. In the group of students with phenotype Hp2-1 we have seen only the tendency to decrease in functional mature T-lymphocyte and their helper subpopulation. In the group of students with phenotype Hp2-2 the relative number of helper T-lymphocyte with the phenotype of CD4+ was reduced after moderate physical activity and it caused the decline in immune regulating index $\mathrm{CD} 4+/ \mathrm{CD} 8+$. Changes of the level of B-lymphocyte with $\mathrm{CD} 72+$ phenotype were not found regardless of the haptoglobin phenotype. Analysis of the impact of moderate physical activity on major classes of serum immunoglobulin revealed the reduction of IgG level in the group of students with phenotype Hp2-2. Thus, we draw the conclusion that serum haptoglobin system shares the adaptive reactions of immune system to moderate physical activity. The most pressing phenotype is Hp2-2. Even in the group of

Черкаський національний університет імені Богдана Хмельницького, бульвар Шевченка, 81, Черкаси, 18031, Украйна. Chercasy State University of Bohdan Khmelnytsky, Shevchenko str., 81, Chercasy, 18031, Ukraine.

Tel.: +38-067-869-17-91.E-mail: sokolenko@ukr.net 
students with immune pressing haptoglobin phenotypes, the analyzed parameters do not go beyond the homeostatic regulations after physical activity and it indicates satisfactory level of immune system adaptation to performed physical activity.

Keywords: haptoglobin; immune system; physical training

\section{Вступ}

Рівень рухової активності - важливий чинник формування стану здоров'я молоді, у тому числі осіб, які навчаються у вищих навчальних закладах. Про тісний зв'язок здоров'я та фізичної працездатності зі способом життя, обсягом і характером повсякденної діяльності повідомлялось у численних дослідженнях, які свідчать про те, що оптимальне фізичне навантаження разом із раціональним харчуванням і правильним способом життя $є$ найефективнішим засобом подолання різноманітних відхилень у стані здоров'я, сприяють попередженню розвитку передпатологічних і патологічних станів (Gani et al., 2003). Стандартизувати такі умови досить складно, особливо у разі проживання студентів у гуртожитках Вагому роль оптимізатора фізичних навантажень можуть виконувати заняття фізичною культурою. Ефективна система фізичного виховання студентів здатна істотно поліпшити здоров'я та фізичну підготовленість. Вона може бути забезпечена за рахунок такого використання засобів і методів, за якого формується довготривалий адаптаційний ефект до навантажень різної природи та інтенсивності (Suzdalnitskiy and Levando, 2003). У той же час не можна забувати про негативний вплив надмірних фізичних зусиль на природну резистентність (Chimenti at al., 2010; Cywińska at al., 2010). Стан імунної системи, що формується у випадку фізичних перенавантажень і при порушенні процесів адаптації організму до них, можна охарактеризувати як виражений і стійкий вторинний імунодефіцит (Suzdalnitskiy and Levando, 2003; Moreira at al., 2006). Важливо сформулювати належні критерії адаптації організму молоді до фізичних навантажень (Gleeson, 2006).

До процесів імунорегуляції за умов екзогенних впливів включаються генетичні маркери крові, роль більшості з яких вивчена недостатньо. Зокрема, це стосується системи гаптоглобінів (Sadrzadeh and Bozorgmehr, 2004). Гаптоглобіни (Нp) - фракція білків гострої фази сироватки крові, найхарактернішою властивістю яких є здатність зв'язуватися 3 гемоглобіном. Гаптоглобін працює як антиоксидант і важливий захисник ендотелію судин. У 1955 році Smithies показав існування трьох типів гаптоглобінів, які позначають як Нp1-1, Нp2-1, Нp2-2. Пізніше було відкрито інші типи гаптоглобінів, але вони зустрічаються рідко (Sadrzadeh and Bozorgmehr, 2004; Quaye, 2008). Тобто система гаптоглобіну характеризується генетичним поліморфізмом. Досліджено функціональні відмінності між окремими фенотипами гаптоглобіну, що мають важливі біологічні та клінічні наслідки. Поліморфізм гаптоглобіну пов'язаний із клінічним розвитком багатьох інфекційних захворювань, атеросклерозом, цукровим діабетом, аутоімунними розладами. Ці явища пояснюються фенотипічно-залежною модуляцією оксидативного стресу та синтезу простагландинів (Levy et al., 2002; Niedowicz and Daleke, 2005; Alegranci et al., 2009). Підтверджена роль гаптоглобінів в імунній відповіді (Quaye, 2008; Mohieldein et al., 2012; Huntoon et al., 2013). Спостерігаються відмінності за чутливістю осіб із різними фенотипами гаптоглобіну до екстремальних факторів середовища, зокрема, радіаційного впливу (Telnov and Zhuntova, 2002).

Вагомим критерієм адаптаційних процесів до фізичних навантажень може бути динаміка показників системи імунітету під час занять фізичною культурою, яка, у свою чергу, певною мірою залежить від імуногенетичних факторів крові. Це зумовило актуальність наших досліджень і визначило мету: 3'ясувати роль фенотипу гаптоглобіну у реалізації адаптивних реакцій показників клітинної та гуморальної ланок імунітету на помірні фізичні навантаження, зумовлені заняттями фізичною культурою.

\section{Матеріал і методи досліджень}

Дослідження показників клітинного та гуморального специфічного імунітету проводили у студентів другого курсу віком 18-20 років, які тривалий час проживали в однакових клімато-географічних умовах. Усі студенти на час обстеження не мали гострих чи хронічних захворювань і відвідували основну групу для занять фізичною культурою. Кількість обстежених - 60 осіб: із фенотипом Нp2-1 - 24, Нp1-1 - 21 і з фенотипом Нp2-2 - 15 осіб.

Аналіз показників імунної системи проводили у вересні, до та після занять фізичною культурою. Основною формою проведення навчально-тренувальних занять був 80-хвилинний оздоровчо-тренувальний процес, побудований за традиційною структурою, що включав вправи, передбачені державною програмою. Контрольний забір крові проводили за добу до навантаження. Другий забір здійснювали відразу після закінчення заняття. Рівень лейкоцитів підраховували в камері Горяєва, лімфоцитів - на основі кров'яного мазка (фарбування барвником Романовського - Гімза). Експресію поверхневих антигенів лімфоцитами периферичної крові визначали імунофлуорисцентним методом із застосуванням моноклональних антитіл до поверхневих маркерів клітин імунної системи LT3, LT4, LT8, 3F3 та F(ab) фрагментів овечих антитіл до IgG миші, мічених FITC («Сорбент», Москва). Рівень імуноглобулінів у плазмі крові визначали методом радіальної імунодифузії за Манчіні з використанням моноспецифічних сироваток проти $\operatorname{Ig} \mathrm{G}(\mathrm{H}), \operatorname{Ig} \mathrm{I}(\mathrm{H}), \operatorname{Ig} \mathrm{A}(\mathrm{H})$. Для оцінки фенотипу гаптоглобіну (Нp) застосовували метод електрофорезу в крохмальному гелі, для порівняння вибірок - однофакторний дисперсійний аналіз.

\section{Результати та їх обговорення}

У студентів після занять фізичною культурою незалежно від фенотипу гаптоглобінів достовірно знижувалося відносне та загальне число лімфоцитів (табл.). Згідно 3 даними літератури (Khaitov and Leskov, 2001; Shirinsky, 2001), зниження рівня лімфоцитів - типова ознака початкових стадій стресової реакції. Таку законо- 
мірність можна узгодити з публікаціями, у яких обгрунтовується положення про фізичний і психоемоційний стрес як головну причину зриву адаптації у спортсменів, що знаходять своє безпосереднє відображення в імунних реакціях організму (Suzdalnitskiy and Levando, 2003).

Останнім часом у спортивних імунодефіцитах виділяють «компенсаторну» групу, що характеризується наростаючою різноспрямованістю імунологічних показників: зниженням одних і компенсаторним підвищенням інших (Suzdalnitskiy and Levando, 2003; Cywińska at al., 2010). Такий ефект схожий з отриманими нами результатами, проте у нашому випадку аналізовані показники як до, так і після фізичних навантажень перебували у межах фізіологічної гомеостатичної норми (табл.). Можна говорити, що наслідок занять фізичною культурою - фізіологічна компенсаторна реакція, яка, на відміну від тривалих і потужних стресових впливів, закінчується простим перерозподілом імунокомпетентних клітин. За даних умов імунітет зберігає здатність захищати організм на досить задовільному рівні за рахунок можливої активації механізмів його неспецифічної ланки (Khaitov and Leskov, 2001; Suzdalnitskiy and Levando, 2003).
Аналіз показників Т-клітинної ланки імунітету включав оцінку експресії Т-лімфоцитами антигенів CD3, $\mathrm{CD} 4, \mathrm{CD} 8$ та імунорегуляторного індексу CD4+/CD8+. Функціональна роль молекули CD3 полягає в тому, що вона бере участь у передачі сигналу від Т-клітинного рецептора (ТКР) всередину клітини, стимулюючи процес іiї активації та проліферації. Комплекс TKР-CD3 найбільш специфічний маркер функціонально зрілих Т-лімфоцитів (Drannik, 1999; Yarilin, 1999). Антигени CD4 та CD8 є маркерами основних субпопуляцій Т-лімфоцитів. Хелперні Т-лімфоцити з фенотипом CD4+головні регуляторні клітини, що продукують різні типи цитокінів і стимулюють клітинну цитотоксичну або гуморальну відповідь (Drannik, 1999; Yarilin, 1999). Цитотоксичні Т-лімфоцити з фенотипом CD8+ спричинюють загибель інфікованих клітин та діють безпосередньо на інфекційні агенти. Частина $з$ них може виконувати регуляторні функції. Зокрема, їм властиві імуносупресорні функції, тобто здатність обмежувати імунну відповідь, запобігати аутоагресії, визначати шляхи розвитку імунних процесів у бік гуморальної чи клітинної відповіді (Drannik, 1999; Yarilin, 1999).

Показники клітинного імунітету в обстежених із різними фенотипами гаптоглобіну

Таблиия до та після занять фізичним вихованням

\begin{tabular}{|c|c|c|c|c|}
\hline \multicolumn{2}{|c|}{ Показники } & Hp2-1 & Hp1-1 & Hp2-2 \\
\hline Лейкоцити, х $10^{9} /$ л & $\begin{array}{c}\text { до навантаження } \\
\text { після навантаження }\end{array}$ & $\begin{array}{l}6,64 \pm 0,105 \\
6,75 \pm 0,845\end{array}$ & $\begin{array}{l}6,71 \pm 0,231 \\
6,86 \pm 0,775\end{array}$ & $\begin{array}{l}6,72 \pm 0,144 \\
6,84 \pm 0,478\end{array}$ \\
\hline Лімфоцити, \% & $\begin{array}{c}\text { до навантаження } \\
\text { після навантаження }\end{array}$ & $\begin{array}{c}27,24 \pm 0,346 \\
25,17 \pm 0,444^{*}\end{array}$ & $\begin{array}{c}26,94 \pm 0,245 \\
23,14 \pm 0,312^{*}\end{array}$ & $\begin{array}{c}26,32 \pm 0,378 \\
20,12 \pm 0,425^{*}\end{array}$ \\
\hline Лімфоцити, х10\% & $\begin{array}{c}\text { до навантаження } \\
\text { після навантаження }\end{array}$ & $\begin{array}{c}1,82 \pm 0,089 \\
1,61 \pm 0,044^{*}\end{array}$ & $\begin{array}{c}1,78 \pm 0,102 \\
1,51 \pm 0,051^{*}\end{array}$ & $\begin{array}{c}1,74 \pm 0,099 \\
1,44 \pm 0,038^{*}\end{array}$ \\
\hline $\mathrm{CD} 3+, \%$ & $\begin{array}{c}\text { до навантаження } \\
\text { після навантаження }\end{array}$ & $\begin{array}{l}65,75 \pm 0,245 \\
65,17 \pm 0,415 \\
\end{array}$ & $\begin{array}{l}65,35 \pm 0,212 \\
64,99 \pm 0,387 \\
\end{array}$ & $\begin{array}{c}65,12 \pm 0,289 \\
63,45 \pm 0,215^{*} \\
\end{array}$ \\
\hline $\mathrm{CD} 3+, \mathrm{x} 10^{9} /$ л & $\begin{array}{c}\text { до навантаження } \\
\text { після навантаження }\end{array}$ & $\begin{array}{l}1,17 \pm 0,034 \\
1,12 \pm 0,035\end{array}$ & $\begin{array}{c}1,15 \pm 0,045 \\
0,99 \pm 0,024^{*}\end{array}$ & $\begin{array}{c}1,14 \pm 0,089 \\
0,91 \pm 0,021^{*}\end{array}$ \\
\hline $\mathrm{CD} 4+, \%$ & $\begin{array}{c}\text { до навантаження } \\
\text { після навантаження }\end{array}$ & $\begin{array}{l}36,41 \pm 0,412 \\
35,64 \pm 0,345\end{array}$ & $\begin{array}{l}35,87 \pm 0,512 \\
34,99 \pm 0,415\end{array}$ & $\begin{array}{c}35,45 \pm 0,412 \\
33,41 \pm 0,289 *\end{array}$ \\
\hline $\mathrm{CD} 4+, \mathrm{x} 10^{9} /$ л & $\begin{array}{c}\text { до навантаження } \\
\text { після навантаження }\end{array}$ & $\begin{array}{l}0,65 \pm 0,028 \\
0,60 \pm 0,024\end{array}$ & $\begin{array}{c}0,62 \pm 0,035 \\
0,52 \pm 0,014^{*}\end{array}$ & $\begin{array}{c}0,62 \pm 0,045 \\
0,49 \pm 0,010^{*}\end{array}$ \\
\hline $\mathrm{CD} 8+, \%$ & $\begin{array}{c}\text { до навантаження } \\
\text { після навантаження }\end{array}$ & $\begin{array}{l}25,09 \pm 0,421 \\
25,34 \pm 0,312 \\
\end{array}$ & $\begin{array}{l}25,99 \pm 0,421 \\
25,45 \pm 0,312 \\
\end{array}$ & $\begin{array}{l}26,12 \pm 0,465 \\
27,09 \pm 0,415 \\
\end{array}$ \\
\hline $\mathrm{CD} 8+, \mathrm{x} 10^{9} /$ л & $\begin{array}{c}\text { до навантаження } \\
\text { після навантаження }\end{array}$ & $\begin{array}{l}0,43 \pm 0,021 \\
0,41 \pm 0,018\end{array}$ & $\begin{array}{l}0,45 \pm 0,034 \\
0,39 \pm 0,015\end{array}$ & $\begin{array}{c}0,47 \pm 0,045 \\
0,35 \pm 0,010^{*}\end{array}$ \\
\hline CD4+/CD8+ & $\begin{array}{c}\text { до навантаження } \\
\text { після навантаження }\end{array}$ & $\begin{array}{l}1,48 \pm 0,034 \\
1,42 \pm 0,045\end{array}$ & $\begin{array}{l}1,41 \pm 0,084 \\
1,36 \pm 0,045\end{array}$ & $\begin{array}{c}1,40 \pm 0,065 \\
1,21 \pm 0,025^{*}\end{array}$ \\
\hline $\mathrm{CD} 72+, \%$ & $\begin{array}{c}\text { до навантаження } \\
\text { після навантаження }\end{array}$ & $\begin{array}{c}9,91 \pm 0,171 \\
10,12 \pm 0,132 \\
\end{array}$ & $\begin{array}{l}9,64 \pm 0,215 \\
9,99 \pm 0,315 \\
\end{array}$ & $\begin{array}{l}10,15 \pm 0,287 \\
10,01 \pm 0,145 \\
\end{array}$ \\
\hline $\mathrm{CD} 72+, \mathrm{x} 10^{9} /$ л & $\begin{array}{c}\text { до навантаження } \\
\text { після навантаження }\end{array}$ & $\begin{array}{l}0,18 \pm 0,008 \\
0,17 \pm 0,009\end{array}$ & $\begin{array}{l}0,16 \pm 0,015 \\
0,15 \pm 0,008\end{array}$ & $\begin{array}{l}0,19 \pm 0,098 \\
0,17 \pm 0,045\end{array}$ \\
\hline $\operatorname{IgG}$, мг/мл & $\begin{array}{c}\text { до навантаження } \\
\text { після навантаження }\end{array}$ & $\begin{array}{c}10,01 \pm 0,213 \\
9,45 \pm 0,312\end{array}$ & $\begin{array}{l}9,97 \pm 0,314 \\
9,15 \pm 0,315 \\
\end{array}$ & $\begin{array}{c}9,91 \pm 0,478 \\
8,45 \pm 0,245^{*}\end{array}$ \\
\hline $\operatorname{IgM,~мг/мЛ~}$ & $\begin{array}{c}\text { до навантаження } \\
\text { після навантаження }\end{array}$ & $\begin{array}{l}1,62 \pm 0,112 \\
1,61 \pm 0,099\end{array}$ & $\begin{array}{l}1,57 \pm 0,214 \\
1,59 \pm 0,113\end{array}$ & $\begin{array}{l}1,65 \pm 0,514 \\
1,62 \pm 0,215\end{array}$ \\
\hline IgA, мг/мЛ & $\begin{array}{c}\text { до навантаження } \\
\text { після навантаження }\end{array}$ & $\begin{array}{l}1,81 \pm 0,093 \\
1,82 \pm 0,123\end{array}$ & $\begin{array}{l}1,84 \pm 0,105 \\
1,81 \pm 0,088\end{array}$ & $\begin{array}{l}1,84 \pm 0,214 \\
1,80 \pm 0,097\end{array}$ \\
\hline
\end{tabular}

Примітка: ${ }^{*}-P<0,05$.

У випадку розвитку дисбалансу між кількістю та активністю CD4+ та CD8+ клітин механізми імунної відповіді будуть порушені. Тому ці субпопуляції Т-лімфоцитів відносяться до імунорегуляторних клітин, співвід- ношення яких визначає силу імунної відповіді (Drannik, 1999; Yarilin, 1999).

Згідно 3 даними літератури, фізичні навантаження високої інтенсивності пригнічують переважно Т-систему імунітету. Це виражається у зниженні відносної та 
абсолютної кількості Т-лімфоцитів, їх метаболічної та функціональної активності. При імунодефіциті, що виникає у разі фізичного перенавантаження та перетренованості, разом із загальним пригніченням Т-системи імунітету спостерігається порушення взаємозв'язків між різними субпопуляціями імунокомпетентних клітин (Suzdalnitskiy and Levando, 2003; Moreira at al., 2006). У наших дослідженнях після занять фізичним вихованням спостерігається достовірне зниження загального числа всіх аналізованих субпопуляцій Т-лімфоцитів (без виходу за межі норми) у студентів, які мають фенотип Нр2-2, що, очевидно, є наслідком змін загального рівня лімфоцитів у периферичній крові. В обстежених із фенотипом Нp1-1 знижується абсолютне число Т-лімфоцитів із фенотипами CD3+ та CD4+. В обстежених із фенотипом Нp2-1 спостерігається лише тенденція до зниження рівня функціонально зрілих Т-лімфоцитів та їх хелперної субпопуляції (табл. 1).

Аналіз відносного числа показників, який, по суті, відображає функціональний стан Т-клітинної ланки імунітету, продемонстрував відсутність статистично достовірних змін в обстежених із фенотипами Нp1-1 та Нp2-1. Спостерігається тенденція до зниження відносного числа функціонально зрілих Т-лімфоцитів із фенотипом CD3+ та їх регуляторної субпопуляції 3 фенотипом CD4+ на фоні практично відсутніх змін відсотка Т-клітин із фенотипом CD8+ (див. табл.). Це, у свою чергу, викликало тенденцію до зниження індексу імунореактивності (не має статистично достовірної значимості). Після занять фізичним вихованням стан Т-клітинної ланки імунітету в цих обстежених залишається на задовільному рівні.

В обстежених із фенотипом Нр2-2, після помірних фізичних навантажень, вірогідно знижується відносне число хелперних Т-лімфоцитів із фенотипом CD4+, що зумовило зниження у них імунорегуляторного індексу CD4+/CD8+ (див. табл.).

Ми проаналізували вплив помірних фізичних навантажень на сироваткові імуноглобуліни. За даними літератури, надмірні навантаження викликають накопичення в крові великих кількостей проміжних продуктів обміну, внаслідок чого відбувається значний зсув кислотнолужної рівноваги у кислий бік та істотне підвищення температури. Це викликає активацію ряду ферментів, у тому числі протеаз, здатних руйнувати на дрібні фрагменти структуру імуноглобулінових молекул, що викликає зниження їх рівня. Паралельно зі зміною $p H$ відбувається посилений викид імунотропних гормонів, які можуть зв'язуватися з альбуміном і глобулінами. Цей процес супроводжується подальшим зниженням рівня імуноглобулінів. Повна елімінація імуноглобулінів із сироватки відбувається у результаті їх сорбції (фіксаціі) численними рецепторами, у тому числі Fc на клітинах крові та багатьох інших клітинах організму (Gleeson, 2006).

Зниження рівня всіх класів імуноглобулінів - закономірний наслідок інтенсивних фізичних навантажень. В окремих дослідженнях є дані про можливе підвищення рівня IgA на фоні зниження рівня інших класів (Suzdalnitskiy and Levando, 2003; Moreira at al., 2006).

$\operatorname{IgG}$ - головний клас сироваткових антитіл за вторинної імунної відповіді. Володіє здатністю проникати через плацентарний бар'єр, тому у перші тижні життя новонароджених є головним засобом їх захисту від інфекцій. Має велике значення для опсонізації бактеріальних токсинів та мікроорганізмів. Концентрація IgG найвища серед імуноглобулінів у сироватці крові. Володіючи високою специфічністю, IgG бере активну участь в імунній відповіді i, одночасно, регулює iіi, впливаючи на активність інших механізмів імунної відповіді (клітинного та гуморального), визначаючи, в кінцевому результаті, повноцінність імунної відповіді (Drannik, 1999; Yarilin, 1999).

$\operatorname{IgA}$ - присутній у сироватці крові у мономерній формі, димерна форма міститься переважно в секретах слизових оболонок і захищає їх від проникнення інфекції. Сироватковий $\operatorname{IgA}$ здатний знешкоджувати мікроби та токсини, що циркулюють у крові, проте його дія слабкіша, ніж секреторного IgA (Drannik, 1999; Yarilin, 1999).

$\operatorname{IgM}$ - перший бар'єр на шляху інфекції. Еволюційно він з'явився раніше, ніж інші класи імуноглобулінів. На мембрані В-лімфоциту існує у вигляді мономера, $є$ типовим антигенспецифічним рецептором цих клітин. Після активації В-лімфоцити секретують спочатку пентамерний $\operatorname{IgM}$, а потім переключаються на IgG або інші класи імуноглобулінів. Зі збільшенням синтезу IgG та зростанням його титру різко гальмується синтез малоспецифічних IgM, який регулюється лише рівнем відповідного за специфічністю IgG. Синтез IgM, оскільки в ньому не беруть участі Т-лімфоцити, резистентний до дії імунодепресантів і опромінення (Drannik, 1999; Yarilin, 1999).

У нашому випадку після помірних фізичних навантажень вірогідні зміни рівня імуноглобулінів виявлені лише для IgG: в обстежених із фенотипом Нp2-2 показник знижується. В обстежених 3 іншими фенотипами демонструє лише тенденцію до зниження (див. табл.).

Ми проаналізували також вплив помірних фізичних навантажень на рівень В-лімфоцитів, що експресують антиген CD72. Молекула CD72 є рецептором для IgM i лігандом для молекул CD5, розміщених на Т-клітинах, забезпечує ефективний контакт із хелперними Т-лімфоцитами. Функціонально зрілі В-лімфоцити є попередниками антитілопродукувальних плазматичних клітин, i, відповідно, клітинним фактором гуморального специфічного імунітету (Drannik, 1999; Yarilin, 1999). Виявлено відсутність вірогідних змін відсотка та абсолютного числа клітин із фенотипом CD72+, незалежно від фенотипу гаптоглобіну (див. табл. 1). Відповідно, ще раз підтверджуються дані літератури, згідно з якими фізичні навантаження високої інтенсивності пригнічують переважно Т-систему імунітету та практично не впливають на В-ланку у початковій стадії адаптаційного процесу (Suzdalnitskiy and Levando, 2003; Moreira et al., 2006).

Отримані результати узгоджуються з більшістю сучасних досліджень, які демонструють пресинг гомозиготних фенотипів Нр (особливо фенотипу Нp2-2) на фізіологічні процеси. Вплив гаптоглобіну на регуляцію імунної відповіді можна пояснити його включенням у різні функції імунокомпетентних лімфоцитів, гранулоцитів і моноцитів (Sadrzadeh and Bozorgmehr, 2004; Mogarekar and Hampe, 2013). 


\section{Висновки}

Сироваткова система гаптоглобінів Нр може включатися в адаптивні реакції показників імунної системи на помірні фізичні навантаження. Найбільш пресинговим для імунної системи за умов фізичних навантажень $\epsilon$ фенотип Нр2-2. Навіть в осіб з імунопресинговими фенотипами гаптоглобіну аналізовані показники після занять фізичним вихованням не виходять за межі гомеостатичної норми. Це свідчить про задовільний рівень адаптації імунної системи до виконаного обсягу фізичних навантажень.

\section{Бібліографічні посилання}

Alegranci, P., de Mattos, L.C., de Godoy, M.F., Moreira, H.W., 2009. Haptoglobin polymorphism correlated with coronary artery disease. Arch. Med. Sci. 5, 32-37.

Chimenti, L., Morici, G., Patern, A., Santagata, R., Bonanno, A., Riccobono, L., Bellia, V., Bonsignore, M., 2010. Bronchial epithelial damage after a half-marathon in nonasthmatic amateur runners. Am. J. Physiol. Lung. Cell Mol. Physiol. 298(6), 857-862.

Cywińska, A., Wyszyńska, Z., Gyrecka, R., Szarska, E., Witkowski, L., Dziekan, P., Winnicka, A., Schollenberger, A., 2010. The effect of the $162 \mathrm{~km}$ endurance ride on equine peripheral blood neutrophil and lymphocyte functions. Pol. J. Vet. Sci. 13(2), 279-285.

Drannik, G.N., 1999. Clinical immunology and allergology [Klinicheskaja immunologija i allergologija]. Astroprint, Odessa (in Russian).

Gani, F., Passalacqua, G., Senna, G., Mosca Frezet, M., 2003. Sport, immune system and respiratory infections. Eur. Ann. Allergy Clin. Immunol. 35(2), 41-46.

Gleeson, M., 2006. Immune system adaptation in elite athletes. Curr. Opin. Clin. Nutr. Metab. Care 9(6), 659-965.

Huntoon, K., Russell, L., Tracy, E., Barbour, K., Li, Q., Shrikant, P., Berger, F., Garrett-Sinha, L., Baumann, H., 2013. A unique form of haptoglobin produced by murine hematopoietic cells supports B-cell survival, differentiation and immune response. Mol. Immunol. 55(3), 345-354.
Khaitov, R.M., Leskov, V.P., 2001. Immunity and stress [Immunitet i stress]. Ros. Fiziol. Zh. 87(8), 1060-1072 (in Russian).

Levy, A.P., HocHperg, I., Jablonski, K., Resnick, H.E., Lee, E.T., Best, L., 2002. Haptoglobin phenotype is an independent risk factor for cardiovascular disease in individuals with diabetes the strong heart study. J. Am. Coll. Cardiol. 40(11), 1984-1990.

Mogarekar, M.R., Hampe, M.H., 2013. Haptoglobin2-2 phenotype is an additional risk factor of retinopathy in type 2 diabetes mellitus. Ind. J. Hum. Genet. 19(2), 154.

Mohieldein, A., Alzohairy, M., Hasan, M., Khan, A., 2012. Inflammatory markers and haptoglobin polymorphism in Saudi with non-insulin-dependent diabetes mellitus. Glob. J. Health Sci. 5(1), 135.

Moreira, A., Kekkonen, R., Delgado, L., Fonseca, J., Korpela, R., Haahtela, T., 2006. Nutritional modulation of exerciseinduced immunodepression in athletes: A systematic review and meta-analysis. Eur. J. Clin. Nutr. 61(4), 443-460.

Niedowicz, D., Daleke, D., 2005. The role of oxidative stress in diabetic complications. Cell Biochem. Biophys. 43(2), 289-330.

Quaye, I.K., 2008. Haptoglobin, inflammation and disease Trans. R. Soc. Trop. Med. Hyg. 102(8), 735-742.

Sadrzadeh, S.H., Bozorgmehr, J., 2004. Haptoglobin phenotypes in health and disorders. Am. J. Clin. Pathol. Patter. Rev. 121(1), 97-104.

Shirinsky, I., 2001. Social stress disorders and immunity. Russ. J. Immunol. 6(2), 207-214.

Suzdalnitskiy, R.S., Levando, V.A., 2003. Novye podhody k ponimaniju sportivnyh stressovyh immunodeficitov [New approaches to understanding of sports and stress immune deficiency]. Teorija i Praktika Fizicheskoj Kul'tury 1, 26-31

32 (in Russian).

Telnov, V.I., Zhuntova, G.V., 2002. Genotipicheskij analiz biohimicheskogo statusa u ljudej, obluchennyh v znachitel'nyh dozah [Genotypic analysis of biochemical status of people received radioactive irradiation]. Voprosy Med. Himii 44(5), 56-60 (in Russian).

Yarilin, A.A., 1999. Immunology fundamentals [Osnovy immunologii]. Medicina, Moscow (in Russian).

Надійшла до редколегї 24.04.2014 